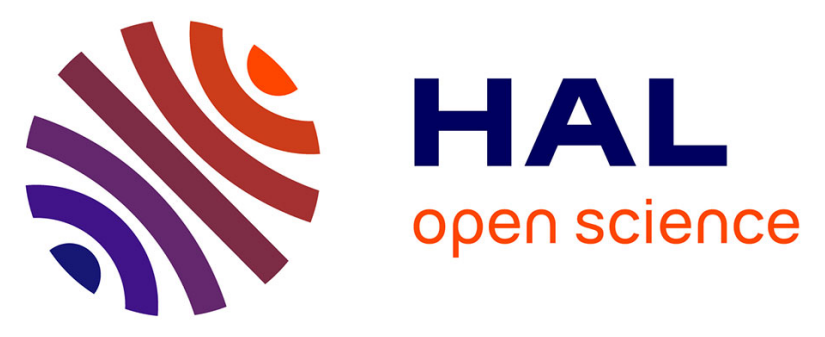

\title{
Use of combined microscopic and spectroscopic techniques to reveal interactions between uranium and Microbacterium sp. A9, a strain isolated from the Chernobyl exclusion zone
}

Nicolas Theodorakopoulos, Virginie Chapon, Frederic Coppin, Magali

Floriani, Thomas Vercouter, Claire Sergeant, Virginie Camilleri, C. Berthomieu, Laureline Fevrier

\section{- To cite this version:}

Nicolas Theodorakopoulos, Virginie Chapon, Frederic Coppin, Magali Floriani, Thomas Vercouter, et al.. Use of combined microscopic and spectroscopic techniques to reveal interactions between uranium and Microbacterium sp. A9, a strain isolated from the Chernobyl exclusion zone. Journal of Hazardous Materials, 2015, 285, pp.285-293. 10.1016/j.jhazmat.2014.12.018 . hal-01561096

\section{HAL Id: hal-01561096 \\ https://hal-amu.archives-ouvertes.fr/hal-01561096}

Submitted on 12 Jul 2017

HAL is a multi-disciplinary open access archive for the deposit and dissemination of scientific research documents, whether they are published or not. The documents may come from teaching and research institutions in France or abroad, or from public or private research centers.
L'archive ouverte pluridisciplinaire HAL, est destinée au dépôt et à la diffusion de documents scientifiques de niveau recherche, publiés ou non, émanant des établissements d'enseignement et de recherche français ou étrangers, des laboratoires publics ou privés.

\section{(2)(1) $\$$}

Distributed under a Creative Commons Attribution - NonCommercial - NoDerivatives 44.0 


\section{Use of combined microscopic and spectroscopic techniques to reveal interactions between uranium and Microbacterium sp. A9, a strain isolated from the Chernobyl exclusion zone}

Nicolas Theodorakopoulos a,b,c,d Virginie Chapona,b,c, Fréderic Coppin ${ }^{\mathrm{d}}$, Magali Florianid Thomas Vercouter $^{\mathrm{e}}$, Claire Sergeant ${ }^{\mathrm{f}, \mathrm{g}}$, Virginie Camilleri ${ }^{\mathrm{d}}$, Catherine Berthomieu ${ }^{\mathrm{a}, \mathrm{b}, \mathrm{c}}$, Laureline Février ${ }^{\mathrm{d}, *}$

a CEA, DSV, IBEB, SBVME, LIPM, F-13108 Saint-Paul-lez-Durance, France

b CNRS, UMR 7265, F-13108 Saint-Paul-lez-Durance, France

' Université d'Aix-Marseille, F-13108 Saint-Paul-lez-Durance, France

d IRSN/PRP-ENV/SERIS/L2BT, bat 183, B.P. 3, F-13115 Saint Paul-lez-Durance, France

e CEA, DEN, DANS, DPC SEARS, LANIE, F-91191 Gif-Sur-Yvette Cedex, France

${ }^{\mathrm{f}}$ Univ Bordeaux, CENBG, UMR5797, F-33170 Gradignan, France

g CNRS, IN2P3, CENBG, UMR5797, F-33170 Gradignan, France

\section{Introduction}

Uranium $(U)$ is a long-lived naturally occurring radionuclide which is both chemo and radio-toxic. Its concentration in European

\footnotetext{
* Corresponding author. Tel.: +334 421995 17; fax: +334 42199151
}

E-mail address: laureline.fevrier@irsn.fr (L. Février) soils ranges from 0.2 to $50 \mathrm{mg} \mathrm{kg}^{-1}$ [1]. Anthropogenic activities such as nuclear fuel production or weapons manufacturing have contributed to the redistribution of this element in the environment. The Chernobyl accident (1986) led to the dispersion of fuel particles of uranium oxide $\left(\mathrm{UO}_{2}\right)$ and mixed zirconium-uranium oxide $\left(\mathrm{Zr}-\mathrm{UO}_{2}\right)$ around the nuclear power plant [2]. Close to the plant, these particles and other radioactive debris were buried in 
radioactive waste repositories, resulting in locally high uranium concentrations [3].

Research focusing on evaluating the mobility of this element and on finding bioremediation processes has been conducted on a worldwide-scale [4]. Importantly, some laboratory experiments have already demonstrated the utility of certain bacteria for reducing uranium mobility. In oxic environments, bacteria may interact directly with uranium through biosorption at the cell surface or by intracellular bioaccumulation, or indirectly through modification of surrounding geochemical conditions, leading to precipitation of $\mathrm{U}[5,6]$. However, the viability of bacteria in these processes is rarely considered, although this factor could be critical to the success of long-term bioremediation applications.

It has already been shown that highly contaminated environments act as potential reservoirs suitable for the isolation of U-resistant bacteria $[7,8]$. In a previous work, we examined a set of 50 bacterial strains isolated from a radioactive waste repository in the Chernobyl exclusion zone [3]. From this screen, we selected a strain affiliated to the genus Microbacterium, which is able to survive $\mathrm{U}(\mathrm{VI})$ exposure. Previous reports on $\mathrm{U}(\mathrm{VI})$ interaction with Microbacterium strains revealed their ability to interact with up to $500 \mu \mathrm{M}$ of $\mathrm{UO}_{2}\left(\mathrm{NO}_{3}\right)_{2}$ [9]. Members of this genus have been detected in radioactive waste contaminated areas or in naturally U-rich soils [10-12], and are thus good candidates to study the interactions of cells with U. Moreover, some Microbacterium species exhibit interesting features such as polymetal resistance [13] and have been proposed for bioremediation applications [14].

The goal of this work was to identify interaction mechanisms employed by living Microbacterium sp. A9 strain cells exposed to a range of $\mathrm{U}(\mathrm{VI})$ concentrations. To distinguish active from passive mechanisms, we varied the experimental temperature, as it influences the activity of bacteria. The survival rate of bacteria was assessed, in addition to the quantification of $\mathrm{U}(\mathrm{VI})$ removal and phosphate release. Finally, the localisation and the speciation of $U$ that interacted with the cells were analysed by microscopic (TEM-EDX) and spectrometric approaches (ATR-FTIR and TRLFS).

\section{Material and methods}

\subsection{Bacterial strain}

The strain Microbacterium sp. A9_3_sp3_12 (referred to here as Microbacterium sp. A9 strain) was isolated from Chernobyl trench T22 soil [3], a contaminated waste storage site located near the Chernobyl nuclear power plant [15]. The strain was routinely cultivated in $0.1 \times$ Tryptic Soy Broth (TSB, Difco Laboratories) at $32^{\circ} \mathrm{C}$ with shaking.

\subsection{Uranium exposure}

The Microbacterium sp. A9 strain was cultivated in $0.1 \times$ TSB medium until the exponential growth phase, and cells were harvested by centrifugation for $10 \mathrm{~min}$ at $5000 \mathrm{~g}$. From this stage on, the samples were maintained either at $4{ }^{\circ} \mathrm{C}$ or at $25^{\circ} \mathrm{C}$ throughout the experiment. The cell pellets were washed twice in $0.1 \mathrm{M} \mathrm{NaCl}$ and were re-suspended at about $6 \times 10^{9}$ bacteria $\mathrm{mL}^{-1}$ in $0.1 \mathrm{M} \mathrm{NaCl}$ pH 5 with 0,10 or $50 \mu \mathrm{M} \mathrm{U}(\mathrm{VI})$. U(VI) was added as uranyl nitrate $\mathrm{UO}_{2}\left(\mathrm{NO}_{3}\right)_{2} \cdot 6 \mathrm{H}_{2} \mathrm{O}$ (Sigma-Aldrich) from a $7.51 \mathrm{mM}$ stock solution in $0.016 \mathrm{M} \mathrm{HNO}_{3}$. The nitrate concentration was adjusted to $0.416 \mathrm{mM}$ by adding $\mathrm{NaNO}_{3}$ when needed. Speciation of 10 and $50 \mu \mathrm{M} \mathrm{U}(\mathrm{VI})$ in the exposure media at $25^{\circ} \mathrm{C}$ or $4{ }^{\circ} \mathrm{C}$ was simulated using Visual MINTEQ (ver. 3.0).

Bacteria exposed to $U(V I)$ were incubated with shaking at $25^{\circ} \mathrm{C}$ or $4^{\circ} \mathrm{C}$. Triplicates were made for each condition. Aliquots were taken after $0.5,2,4,6,10$ and $24 \mathrm{~h}$. Blank controls without bacteria were performed to exclude abiotic uranium removal from the exposure solution.

\subsection{Uranium and phosphate quantification}

The samples were centrifuged at $8000 \mathrm{~g}$ for $5 \mathrm{~min}$. $\mathrm{U}$ in the supernatant was analysed by inductively coupled plasmaatomic emission spectrometry (ICP-AES Optima 4300DV, PerkinElmer).

Inorganic phosphate $(\mathrm{Pi})$ in the supernatant was quantified by colorimetric measurements, using the molybdophosphoric acid blue method [16]. Potassium dihydrogen phosphate solutions were used as standards. All measurements were performed at $25^{\circ} \mathrm{C}$ in a 96-well microplate and recorded at $720 \mathrm{~nm}$.

\subsection{Bacterial viability}

Aliquots of cell suspensions taken at 0.5 and $24 \mathrm{~h}$ were diluted in $0.1 \times$ TSB and spread on $0.1 \times$ TSB agar plates. Colony Forming Units (CFUs) were counted after $24 \mathrm{~h}$ at $30^{\circ} \mathrm{C}$.

\subsection{Microscopy (TEM-EDX) analysis}

Bacterial cell pellets were fixed in sodium cacodylate buffer (0.1 M, pH 7.4) supplemented with $2.5 \%$ glutaraldehyde. After $24 \mathrm{~h}$ at $4{ }^{\circ} \mathrm{C}$, the samples were washed three times with sodium cacodylate buffer and post-fixed in the same buffer containing $1 \%$ osmium tetroxide $\left(\mathrm{OsO}_{4}\right)$ for $1 \mathrm{~h}$. The samples were dehydrated through a graded ethanol series, and finally embedded in an Epon 812 resin. All chemicals used for histological preparation were purchased from Electron Microscopy Sciences. Samples were cut in ultra-thin sections using a UCT ultramicrotome (Leica Microsystems $\mathrm{GmbH}$ ). Sections were then mounted on copper grids and examined with a Scanning Transmission Electron Microscope (TEM/STEM; Tecnai $G^{2}$ Biotwin, FEI) equipped with a CCD camera Megaview III (Olympus Soft Imaging Solutions GmbH). At least 200 images were analyzed for each condition. The localization of $U$ was conducted using a Phoenix Energy Dispersive X-ray analyzer (EDAX Inc.) equipped with a Super Ultra-Thin Window model sapphire detector with a counting time of $100 \mathrm{sec}$.

\subsection{Time-resolved laser-induced fluorescence spectroscopy (TRLFS)}

Since the temperature of the TRLFS analytical design could not be controlled, only samples that were exposed to $25^{\circ} \mathrm{C}$ were analyzed. Cell pellets were washed five times with ultrapure water to remove labile $U$ and to avoid fluorescence quenching linked to the presence of $\mathrm{Cl}^{-}$ions. Cell pellets were re-suspended in ultrapure water and transferred to a 96-well black quartz microplate for analyses. A pulsed laser (Continuum Minilite; $5 \mathrm{~ns} /$ pulse, $10 \mathrm{~Hz}$ ) with an emission wavelength of $266 \mathrm{~nm}$ was used for excitation. The fluorescence emission was collected with an optical fiber and the intensity was recorded from 376 to $669 \mathrm{~nm}$ using a monochromator and a CCD camera (Spectrophotometer Andor Technology SR-303iA) with a spectral resolution of $0.14 \mathrm{~nm}$. The time-resolved spectra were recorded between 1 and $96 \mu$ s; a step width of $0.5 \mu$ s was used from 1 to $6 \mu \mathrm{s}$, and a step width of $5 \mu \mathrm{s}$ was used from 6 to $96 \mu \mathrm{s}$, with a gate width of $20 \mu \mathrm{s}$. One hundred laser flashes were accumulated for each spectrum. Lifetimes were calculated as described in Vercouter et al. [17]. For a reference, U-phosphate complex $\left(\mathrm{UO}_{2}\left(\mathrm{H}_{2} \mathrm{PO}_{4}\right)_{2}\right)$ was prepared by mixing $\mathrm{UO}_{2}\left(\mathrm{NO}_{3}\right)_{2}\left(1 \mathrm{mg} \mathrm{L}^{-1}\right)$ with $\mathrm{H}_{3} \mathrm{PO}_{4}(0.5 \mathrm{M})$. 


\subsection{Attenuated total reflection fourier transform infra-red spectroscopy (ATR-FTIR)}

The cell pellets were washed with ultrapure water and were deposited and dried on the ATR surface (a 9 bounce diamond microprism with a $4.3 \mathrm{~mm}$ surface diameter and ZnSe optics; SensIr Technologies) to avoid background absorption from water. All infrared spectra were recorded with a $4 \mathrm{~cm}^{-1}$ resolution in the $4000-400 \mathrm{~cm}^{-1}$ range, using a Bruker IFS28 FTIR spectrometer equipped with a DTGS detector (SensIR ATR Setup). Two spectra were acquired for each condition. Typically, 300 scans were accumulated for each spectrum.

\subsection{Statistical analyses}

All statistical analyses were performed with $\mathrm{R}$ software [18]. Results of cell viability and Pi release were analyzed by ANOVA, after checking assumptions of normality and variance homogeneity of residuals. Alpha levels were $\leq 0.05\left({ }^{*}\right)$ and $\leq 0.001\left({ }^{* *}\right)$. Data were presented as mean \pm standard deviation of the mean.

\section{Results}

\section{1. $U(V I)$ speciation in the exposure media}

As no precipitate was observed during the preparation of our exposure media, precipitation has been excluded from the simulations of $\mathrm{U}(\mathrm{VI})$ speciation. $\mathrm{U}(\mathrm{VI})$ was mainly present as bioavailable forms $\left(\mathrm{UO}_{2}{ }^{2+}\right.$ and $\mathrm{UO}_{2} \mathrm{OH}^{+}$) (Table 1) [19]. At $50 \mu \mathrm{M}$, bioavailable $\mathrm{U}(\mathrm{VI})$ forms constituted $60 \%$ (at $25^{\circ} \mathrm{C}$ ) and $80 \%$ (at $4{ }^{\circ} \mathrm{C}$ ) of the soluble $\mathrm{U}(\mathrm{VI})$ forms, whereas they constituted $86 \%\left(25^{\circ} \mathrm{C}\right)$ and $94 \%$ $\left(4^{\circ} \mathrm{C}\right)$ at $10 \mu \mathrm{M}$.

\subsection{Bacterial viability upon $U(V I)$ exposure}

No mortality was measured in the controls without $\mathrm{U}(\mathrm{VI})$ after $24 \mathrm{~h}$ at $4{ }^{\circ} \mathrm{C}$ and $25^{\circ} \mathrm{C}$, indicating that bacteria remained viable during the experiment (Fig. 1). Similar results were obtained for the samples incubated at $4{ }^{\circ} \mathrm{C}$ with both $\mathrm{U}(\mathrm{VI})$ concentrations and the samples incubated at $25^{\circ} \mathrm{C}$ with $10 \mu \mathrm{M} \mathrm{U}(\mathrm{VI})$. In contrast, incuba-
Table 1

Simulation of $\mathrm{U}(\mathrm{VI})$ speciation in the exposure solutions.

\begin{tabular}{|c|c|c|c|c|}
\hline \multirow[t]{2}{*}{ Species name } & $50 \mu \mathrm{M} 25^{\circ} \mathrm{C}$ & $50 \mu \mathrm{M} 4{ }^{\circ} \mathrm{C}$ & $10 \mu \mathrm{M} 25^{\circ} \mathrm{C}$ & $10 \mu \mathrm{M} 4{ }^{\circ} \mathrm{C}$ \\
\hline & \multicolumn{4}{|c|}{ (\%) of total concentration } \\
\hline $\mathrm{UO}_{2}{ }^{2+}$ & 46.96 & 63.17 & 67.53 & 73.83 \\
\hline $\mathrm{UO}_{2} \mathrm{OH}^{+}$ & 12.66 & 17.00 & 18.19 & 19.84 \\
\hline$\left(\mathrm{UO}_{2}\right)_{2}(\mathrm{OH})_{2}{ }^{2+}$ & 19.98 & 8.39 & 8.25 & 2.29 \\
\hline$\left(\mathrm{UO}_{2}\right)_{3}(\mathrm{OH})_{5}^{+}$ & 14.98 & 0.93 & 1.77 & 0.06 \\
\hline $\mathrm{UO}_{2} \mathrm{Cl}^{+}$ & 2.51 & 2.72 & 3.63 & 3.19 \\
\hline$\left(\mathrm{UO}_{2}\right)_{3}(\mathrm{OH})_{4}{ }^{2+}$ & 1.40 & 3.63 & 0.17 & 0.23 \\
\hline$\left(\mathrm{UO}_{2}\right)_{4}(\mathrm{OH})_{7}^{+}$ & 0.79 & 2.94 & 0.03 & 0.04 \\
\hline$\left(\mathrm{UO}_{2}\right)_{2} \mathrm{OH}^{3+}$ & 0.57 & 1.02 & 0.23 & 0.28 \\
\hline $\mathrm{UO}_{2}(\mathrm{OH})_{2}$ & 0.12 & 0.17 & 0.18 & 0.20 \\
\hline $\mathrm{UO}_{2} \mathrm{NO}_{3}{ }^{+}$ & 0.01 & 0.03 & 0.02 & 0.03 \\
\hline
\end{tabular}

tion at $25^{\circ} \mathrm{C}$ in the presence of $50 \mu \mathrm{M} \mathrm{U}(\mathrm{VI})$ led to $61 \%$ mortality after $24 \mathrm{~h}$.

\subsection{Sequestration by Microbacterium sp. A9 strain}

The kinetics of $\mathrm{U}(\mathrm{VI})$ removal from the exposure solution by bacterial cells was determined by measuring $U$ content in the supernatant (Fig. 2). Abiotic controls showed that $\mathrm{U}(\mathrm{VI})$ remains soluble within the $24 \mathrm{~h}$ exposure in all conditions and confirmed that $\mathrm{U}(\mathrm{VI})$ removal resulted exclusively from biotic interaction. Within the first $30 \mathrm{~min}$ of exposure at $50 \mu \mathrm{M} \mathrm{U}(\mathrm{VI}), 78 \%$ of the initial amount of $\mathrm{U}(\mathrm{VI})$ was removed from the supernatant at both temperatures (Fig. 2B). Then, $\mathrm{U}(\mathrm{VI})$ removal reached an apparent equilibrium at $4{ }^{\circ} \mathrm{C}$, whereas it continued at $25^{\circ} \mathrm{C}$. The proportions of $\mathrm{U}(\mathrm{VI})$ removed from the supernatant after $24 \mathrm{~h}$ were $94 \%$ and $86 \%$ at $25^{\circ} \mathrm{C}$ and $4{ }^{\circ} \mathrm{C}$, respectively.

At $10 \mu \mathrm{M} \mathrm{U}(\mathrm{VI})$, a rapid metal removal corresponding to more than $90 \%$ of the total $\mathrm{U}(\mathrm{VI})$ took place within the first $30 \mathrm{~min}$ at both temperatures (Fig. 2A). After this step, great differences were observed between the two temperatures. At $4{ }^{\circ} \mathrm{C}, \mathrm{U}(\mathrm{VI})$ removal ceased and the system remained stable until the end of the experiment. By contrast, $\mathrm{U}(\mathrm{VI})$ release in the exposure medium at $25^{\circ} \mathrm{C}$ was observed between 0.5 and $4 \mathrm{~h}$, followed by a slow $\mathrm{U}(\mathrm{VI})$ removal that finally resulted in a total accumulation of $86 \% \mathrm{U}(\mathrm{VI})$ after $24 \mathrm{~h}$.

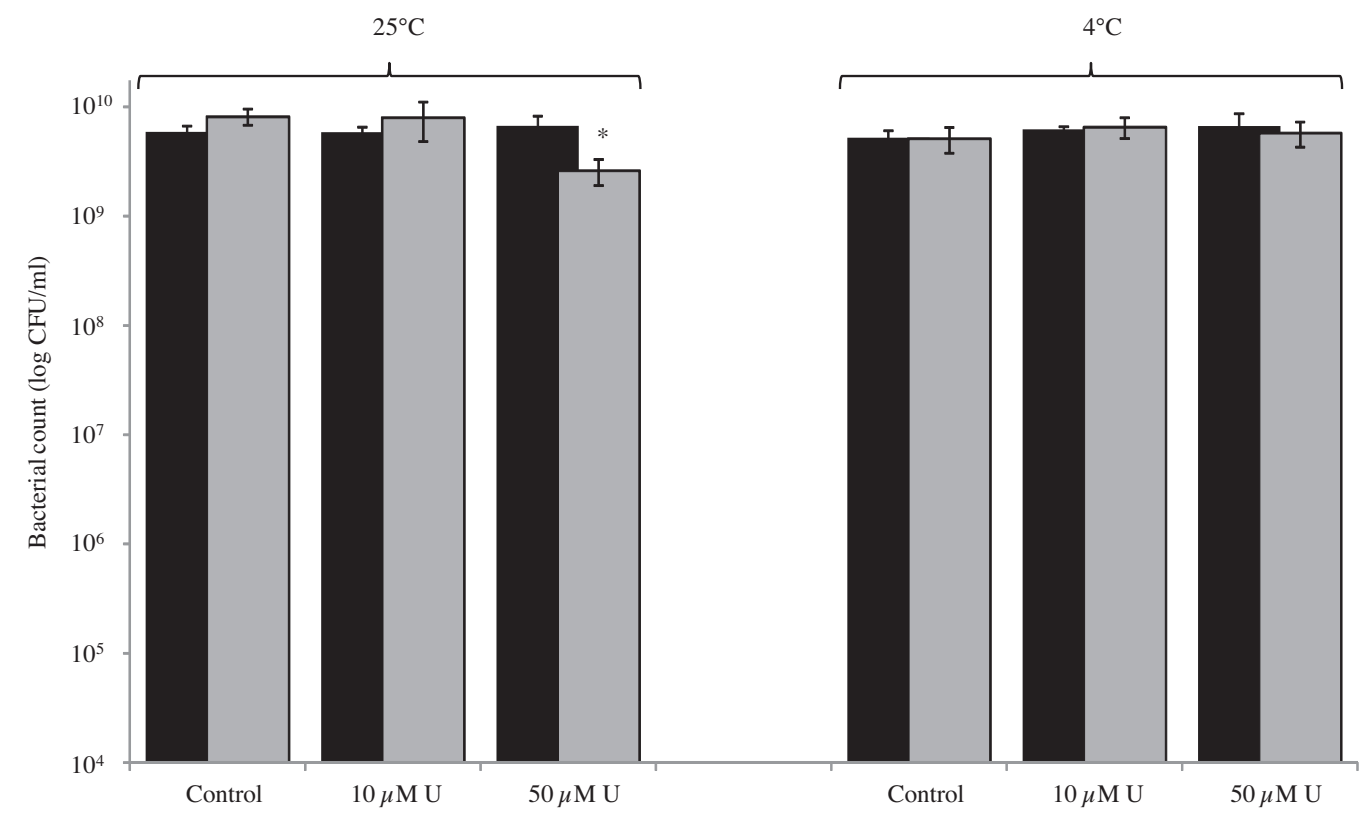

Fig. 1. Cell viability at $0.5 \mathrm{~h}$ (black column) and $24 \mathrm{~h}$ of exposure (grey column) to $0 \mu \mathrm{M}$ (control), $10 \mu \mathrm{M}$ and $50 \mu \mathrm{M} \mathrm{U}(\mathrm{VI})$ at 4 and $25^{\circ} \mathrm{C}$. 


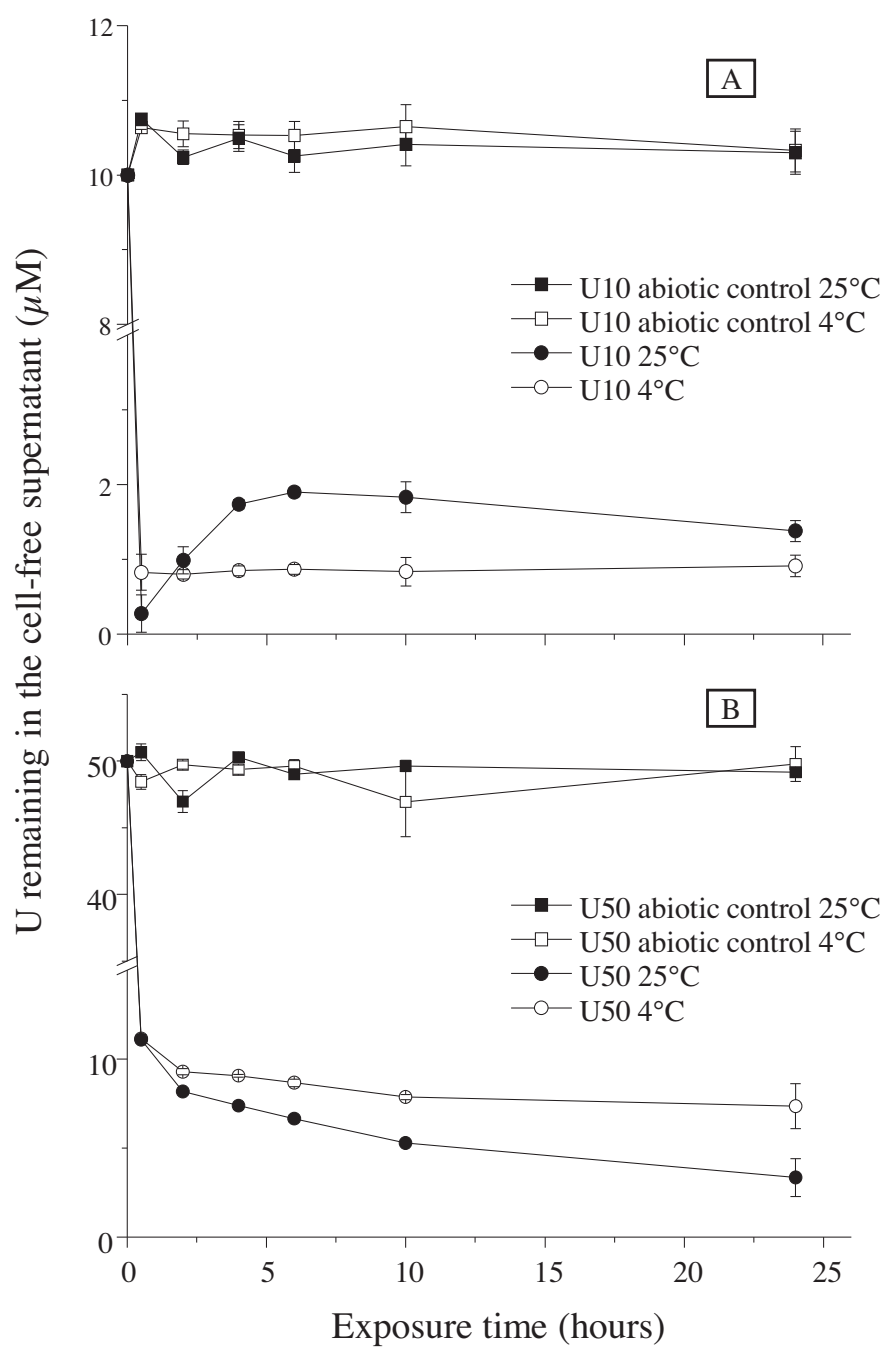

Fig. 2. $U$ concentration over time in the cell-free supernatant during cell exposure to $10 \mu \mathrm{M}(\mathrm{A})$ and $50 \mu \mathrm{M}(\mathrm{B}) \mathrm{U}(\mathrm{VI})$ at $4{ }^{\circ} \mathrm{C}$ (open symbols) and $25^{\circ} \mathrm{C}$ (filled symbols). Abiotic controls are represented by squares; biotic conditions are represented by circles.

\subsection{Pi release during $U(V I)$ exposure}

We measured Pi content in all supernatants, since its release by cells can strongly influence $U$ speciation and solubility. At $4{ }^{\circ} \mathrm{C}$, a constant and low quantity of $\mathrm{Pi}(7.4 \pm 0.76 \mu \mathrm{M}$ in average) was measured in the supernatants and no statistically significant differences were found between the control samples without $\mathrm{U}(\mathrm{VI})$ and samples exposed to $10 \mu \mathrm{M} \mathrm{U}(\mathrm{VI})$ (Fig. 3A). However, for an unexplained reason, in the control samples, this amount was high compared to that observed at $25^{\circ} \mathrm{C}$ at the beginning of the incubation. Nevertheless, strong differences appeared at longer time of incubation. For cells exposed to $50 \mu \mathrm{M} \mathrm{U}(\mathrm{VI})$, the Pi concentration values were always significantly lower than in the other conditions and showed a strong decline during the incubation. At the end of the experiment, the Pi concentration was 7-fold lower $(1 \mu \mathrm{M})$ than in the control samples.

At $25^{\circ} \mathrm{C}$ (Fig. 3B), an increase in Pi content was observed over the time-course of the experiment for all conditions, yet to different extents. The maximum Pi release occurred for cells exposed to $10 \mu \mathrm{M} \mathrm{U}(\mathrm{VI})$, with the exception of the $24 \mathrm{~h}$ time point, where the highest value was measured in the control sample $(43 \mu \mathrm{M})$. In the $50 \mu \mathrm{M} \mathrm{U}(\mathrm{VI})$ condition, Pi concentrations exhibited values 2.5 to 4 -fold lower than in the other conditions after $6 \mathrm{~h}$ of exposure.

\subsection{Microscopic observations of U(VI)-exposed cells}

TEM- EDX analysis revealed needle-like structures inside the bacteria that contain $U$ (Fig. 4). These structures were detected exclusively in the samples incubated at $25^{\circ} \mathrm{C}$ and exposed to $\mathrm{U}(\mathrm{VI})$ for at least $6 \mathrm{~h}$, and their size increased as a function of time. EDX analysis revealed that $U$ in these structures co-localised mainly with phosphorus (P) and calcium (Ca).

\subsection{Analysis of U speciation with TRLFS}

$\mathrm{U}$ speciation was analyzed by TRLFS on bacterial cells exposed to both $\mathrm{U}(\mathrm{VI})$ concentrations at $25^{\circ} \mathrm{C}$ for $0.5,6$ and $24 \mathrm{~h}$. Information regarding possible $U$ species can be determined by analyzing both the static emission fluorescence spectrum band position and the time-resolved fluorescence decay. The emitted signal recorded for the cells exposed to $10 \mu \mathrm{M} \mathrm{U}(\mathrm{VI})$ was too low. The two spectra recorded for cells exposed to $50 \mu \mathrm{M} \mathrm{U}$ after 6 and $24 \mathrm{~h}$ of exposure were characterized by emission maxima at 494, 516 and $539 \mathrm{~nm}$ (Fig. 5). Two additional important shoulders, characterized by emis-

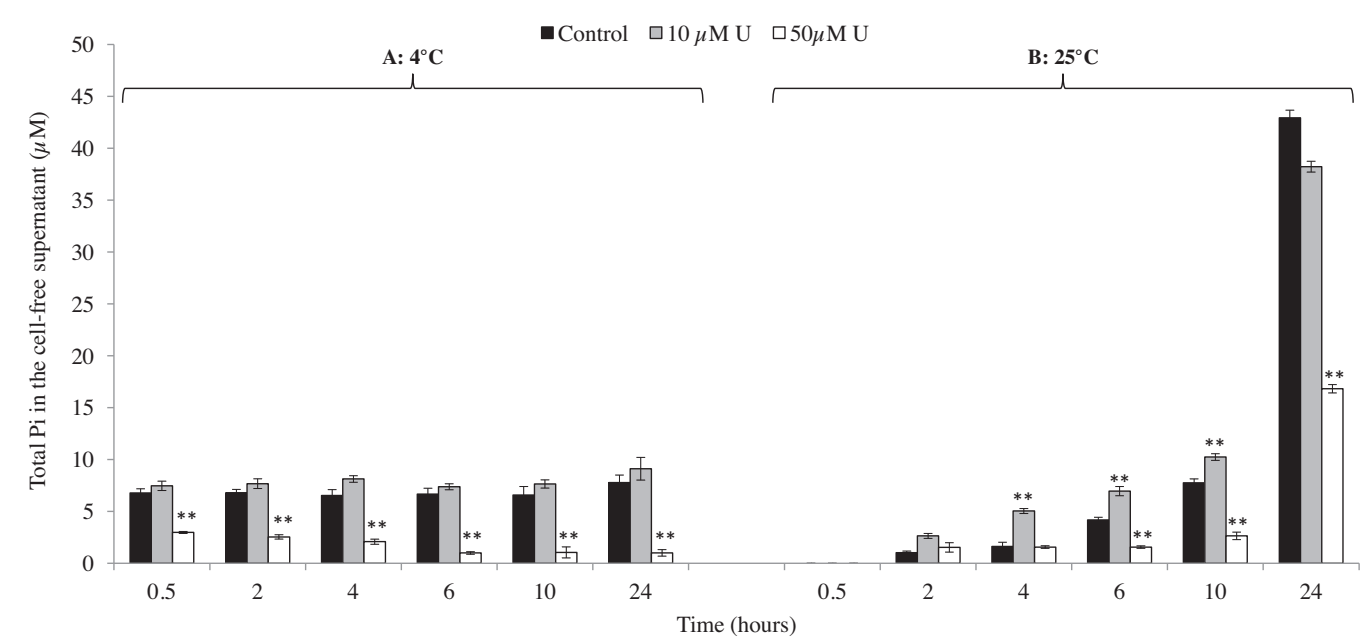

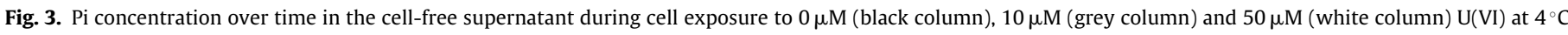
(A) and $25^{\circ} \mathrm{C}(\mathrm{B})$. 

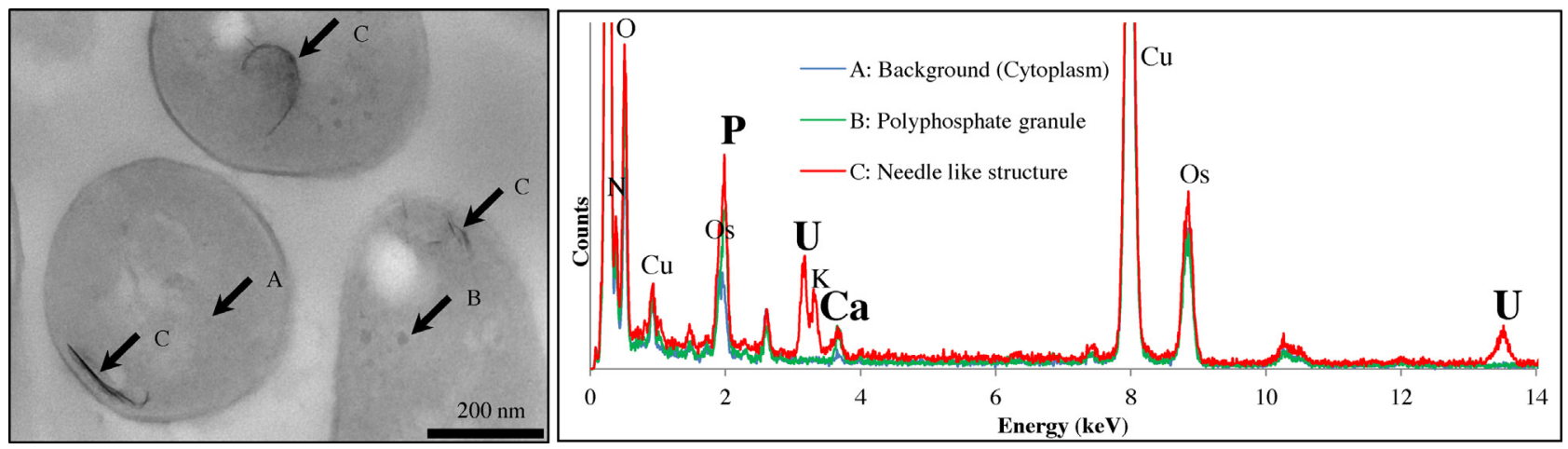

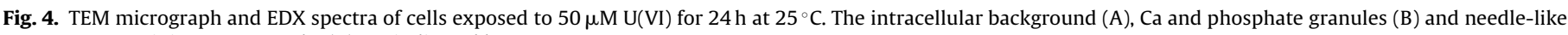
structures containing $\mathrm{U}, \mathrm{Ca} \mathrm{K}$ and $\mathrm{P}(\mathrm{C})$ are indicated by arrows.

sions at 503 and $523 \mathrm{~nm}$, were recorded for cells exposed for $24 \mathrm{~h}$. Spectra of cells exposed for $0.5 \mathrm{~h}$ exhibited a low signal-to-noise ratio with poorly resolved emission peaks, although they followed the same trend observed in the other spectra.

The emission maxima of exposed cells coincide with those of our U-phosphate reference complex (Fig. 5: spectrum (A), 494, 516, 539 , and $565 \mathrm{~nm})$. However, the construction of a convoluted spectrum based only on the presence of the U-phosphate complex and background noise indicates that a second compound with emission maxima corresponding to those of autunite (Fig. 5: spectrum (B), 503, 523, 547 and $573 \mathrm{~nm}$ ) must be considered. The percentage of autunite needed to fit the spectra of exposed cells increased with exposure time to $\mathrm{U}(\mathrm{VI})$. After $6 \mathrm{~h}$ of exposure to $\mathrm{U}$, the spectra could be explained by $6 \%$ autunite, $34 \% \mathrm{U}$-phosphate complexes and $61 \%$ background noise, whereas after $24 \mathrm{~h}$ of exposure, these values were 15,45 and $40 \%$, respectively.

Luminescence lifetime analyses of the exposed cells did not reveal any differences according to exposure time. All data fit well with a bi-exponential decay curve, confirming the presence of two luminescent species, with first lifetime values of $29.9 \pm 5.4$, $34.4 \pm 4.3$ and $32.6 \pm 3.1 \mu$ s and second lifetime values of $2.0 \pm 0.7$, $3.5 \pm 1.8$ and $2.3 \pm 0.4 \mu \mathrm{s}$ after $0.5,6$ and $24 \mathrm{~h}$ of exposure to $\mathrm{U}(\mathrm{VI})$, respectively. These lifetime values were slightly shorter than those for autunite (105 and $18 \mu \mathrm{s}$ ) and the U-phosphate complex ( $94.6 \pm 3.6$ and $3.1 \pm 0.9 \mu \mathrm{s})$, probably due to the presence of fluorescence quenchers in bacteria [20].

\subsection{Analysis of $U$ coordination by ATR-FTIR}

We further investigated the functional groups involved in $\mathrm{U}(\mathrm{VI})$ complexation by recording ATR-FTIR spectra of non-exposed bacteria (control) as well as bacteria exposed to 10 and $50 \mu \mathrm{M} U$ for $0.5,6$ and $24 \mathrm{~h}$ at both temperatures. For the $10 \mu \mathrm{M}$ condition, the signal was too low. The results in Fig. 6 are presented as difference spectra, i.e. absorption spectra of the bacteria exposed to $50 \mu \mathrm{M}$ minus absorption spectra of the non-exposed bacteria. The spectra of control and exposed cells were calibrated using the main absorption bands of proteins (referred to as Amide I and Amide II bands) to calculate the difference spectra. In these spectra, positive and negative peaks represent vibrational modes of functional groups that undergo changes due to $U$ complexation. This approach primarily revealed a temperature dependence of the difference spectra, as well as spectral changes in response to exposure time at $25^{\circ} \mathrm{C}$. At $4{ }^{\circ} \mathrm{C}$ (Fig. 6A), spectra exhibited only a slight evolution with exposure time. These results are characterized by a clear positive band at $916 \mathrm{~cm}^{-1}$, and by negative bands at $1080,1215,1400 \mathrm{~cm}^{-1}$ and $1570 \mathrm{~cm}^{-1}$. The positive band at $916 \mathrm{~cm}^{-1}$ is assigned to the asymmetric stretching vibration of the uranyl ion and has been observed for uranyl complexes involving functional groups

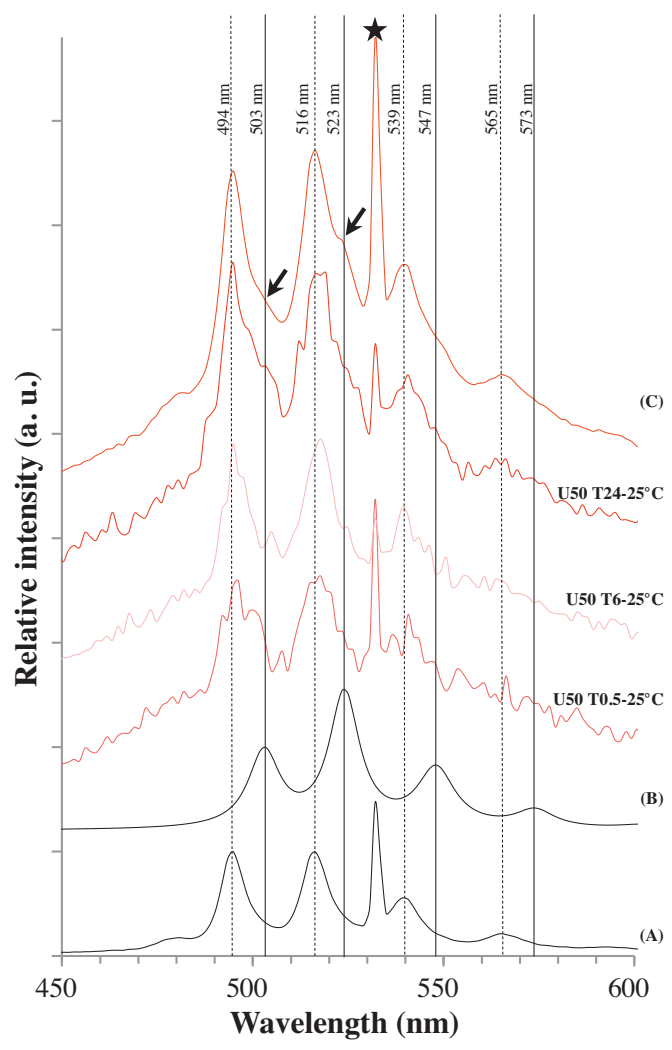

Fig. 5. TRLFS spectra of cells exposed to $50 \mu \mathrm{M} \mathrm{U}(\mathrm{VI})$ for $0.5,6$ and $24 \mathrm{~h}$ at $25^{\circ} \mathrm{C}$, as well as uranyl phosphate reference compounds (A), autunite (B), and the convoluted spectra of $A+B(C)$. The peak marked with a star (') represents the harmonic signal at $532 \mathrm{~nm}$.

belonging to various cellular components [21,22]. The bands at 1570 and $1400 \mathrm{~cm}^{-1}$ are assigned to the asymmetric and symmetric vibrations of carboxylate groups $\left(v_{\text {as }}\right.$ and $\left.v_{\mathrm{s}}\left(\mathrm{COO}^{-}\right)\right)$, suggesting that uranyl is coordinated by carboxylate groups in the cells at $4{ }^{\circ} \mathrm{C}$. In addition, IR bands between 1300 and $1000 \mathrm{~cm}^{-1}$ correspond to bands of phosphoryl or phosphate groups [22,23], showing that these groups may also be involved in uranium binding at $4{ }^{\circ} \mathrm{C}$.

In contrast, the spectra differ significantly at $25^{\circ} \mathrm{C}$ (Fig. 6B) with respect to exposure time. The spectrum recorded after $0.5 \mathrm{~h}$ of cell exposure to $\mathrm{U}(\mathrm{VI})$ at $25^{\circ} \mathrm{C}$ was similar to the spectrum recorded after the same exposure time at $4{ }^{\circ} \mathrm{C}$. This indicates that similar chelation processes occurred shortly after U(VI) exposure at both temperatures, and that these processes involve carboxylate groups as well as phosphoryl or phosphate groups. The bands 


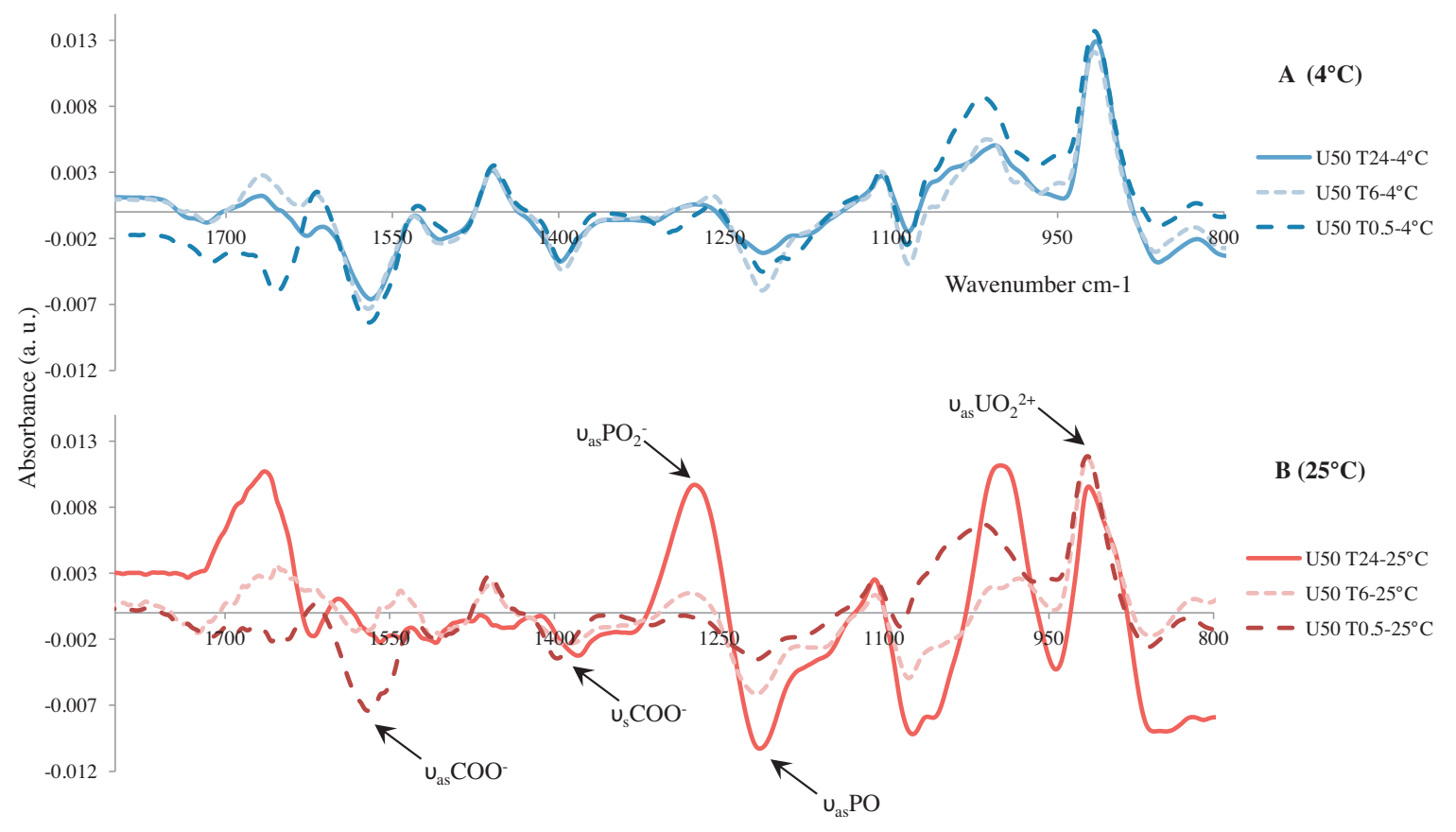

Fig. 6. FTIR differential spectrum between control samples and uranium-exposed bacteria ( 10 and $50 \mu \mathrm{M} \mathrm{U})$ at $0.5,6$ and $24 \mathrm{~h}$, assayed at $4{ }^{\circ} \mathrm{C}(\mathrm{A})$ and $25^{\circ} \mathrm{C}(\mathrm{B})$.

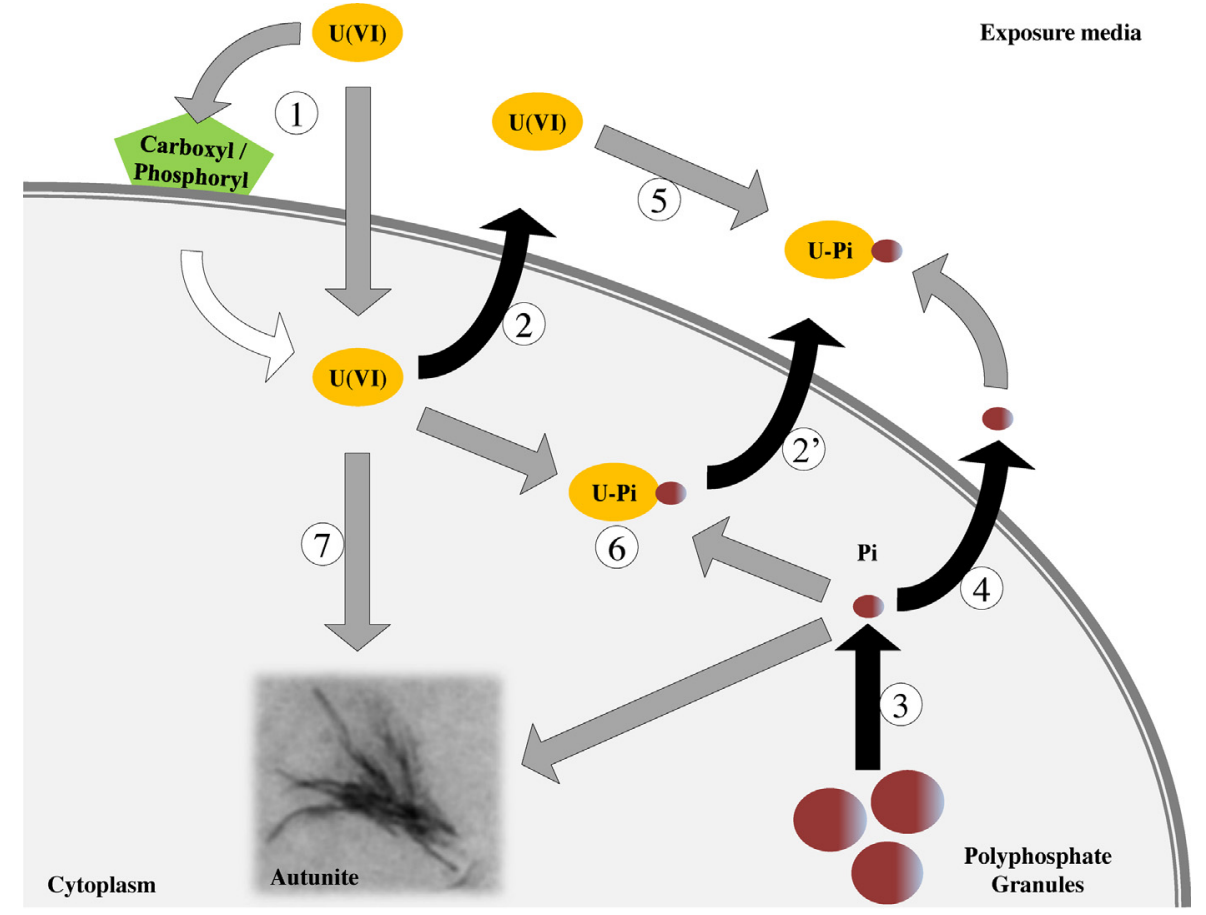

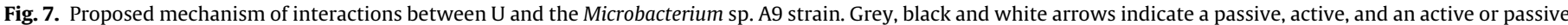

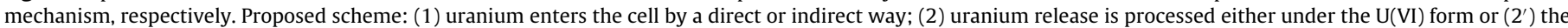

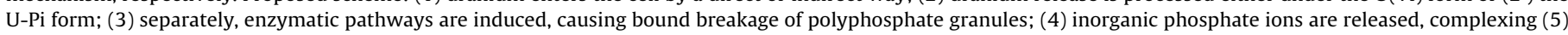
extracellularly and (6) intracellularly with bioavailable uranium; (7) autunite is formed intracellulary when a suitably high U-Pi complex concentration is reached.

assigned to carboxylate groups at 1400 and $1570 \mathrm{~cm}^{-1}$ decreased significantly for spectra recorded after 6 and $24 \mathrm{~h}$ exposure to $\mathrm{U}(\mathrm{VI})$. Furthermore, bands assigned to phosphate and/or phosphoryl groups at 1087,1220 and $1274 \mathrm{~cm}^{-1}$ significantly increased, especially after $24 \mathrm{~h}$ exposure. These changes highlight the role of phosphate groups in the binding of uranium at $25^{\circ} \mathrm{C}$ during longer time scales.

\section{Discussion}

In this work, we describe the interaction of the Microbacterium sp. A9 strain, isolated from a radioactive waste repository, with uranium. Here, by the use of complementary approaches, we evidenced the presence of passive and active mechanisms involved in uranium tolerance. 


\subsection{Resistance of Microbacterium to $U(V I)$}

$\mathrm{U}$ speciation as well as $\mathrm{U}$ bioavailability is influenced by $\mathrm{pH}$, the redox-potential, and the presence of various complexing agents. In our study, cells were exposed in a medium totally devoid of complexing agents in order to optimize $\mathrm{U}(\mathrm{VI})$ bioavailability. We demonstrated that exposure to $10 \mu \mathrm{M} \mathrm{U}(\mathrm{VI})$ in this medium did not impact cell viability. Up to $30 \%$ of Microbacterium sp. A9 cells remained viable despite 24 h exposure to $50 \mu \mathrm{MU}(\mathrm{VI})$. Several environmental isolates affiliated with Microbacterium are reported to be resistant to numerous metal(loid) s such as, chromium, arsenic, cobalt, nickel, selenium, uranium, and zinc [12,14,24,25].

\subsection{Phosphate release and its detoxification role}

Polyphosphate granules are synthesized by many bacteria for both energy and phosphate storage, and can be used in defense mechanisms against metal exposure when needed (reviewed in [26]).

Here, we observed that Pi release was temperature-dependent. At $4{ }^{\circ} \mathrm{C}$, after an initial release upon cell exposure to the acidic saline solution, the Pi concentration remained stable. In contrast, Pi concentration increased significantly at $25^{\circ} \mathrm{C}$, demonstrating that $\mathrm{Pi}$ release is an active process. The efficiency of Pi release was not only temperature-dependent, but also varied according to $\mathrm{U}(\mathrm{VI})$ concentration. Pi release was slightly induced within the first $10 \mathrm{~h}$ when cells were exposed to $10 \mu \mathrm{M} \mathrm{U}(\mathrm{VI})$. In contrast, Pi release was much more limited at $50 \mu \mathrm{M} U(\mathrm{VI})$. This feature could be a consequence of the toxic effect of $\mathrm{U}(\mathrm{VI})$ at $50 \mu \mathrm{M}$, which had a noticeable effect on cell viability. Interestingly, Pi release by bacteria exposed to $10 \mu \mathrm{M} \mathrm{U}(\mathrm{VI})$ occurred with the efflux of $\mathrm{U}$ observed $30 \mathrm{~min}$ after uranyl exposure, suggesting that uranyl may be released as uranyl-phosphate complexes (U-Pi). However, it is not possible to determine if these two release systems are connected. It is therefore very likely that Pi release represents an indirect protection mechanism against uranium, either by promoting U-Pi efflux or by limiting the entrance of $U$ (once it has been extracellulary chelated by Pi).

These results are in agreement with other studies demonstrating that several bacteria species can precipitate uranium in the extracellular compartment via a phosphate release mechanism mediated by non-specific acid phosphatases, thus preventing or limiting its entrance into the cytoplasm (reviewed in [5,27-30]). However, no $U$ precipitates were observed by TEM in the exposure media or at the bacterial surface under our conditions. Therefore, it is more probable that the U-Pi complexes remain soluble in the exposure media.

Finally, the release of Pi appeared to be affected by the intracellular accumulation of $U$. Indeed, 24-hours exposure to either 10 or $50 \mu \mathrm{M} \mathrm{U}(\mathrm{VI})$, conditions in which $\mathrm{U}$ accumulation was observed by TEM (see below), inhibited the release of Pi as compared to controls. This may be due to the total or partial inhibition of phosphatase activity by the uranyl ion [31,32]. It is also possible that phosphate was sequestered in these cells, as part of uraniumphosphate precipitates [33]. Ray et al. [34] also observed that U minimizes the final average concentrations of $\mathrm{Pi}$ in solution, in a bacterial culture exposed to $100 \mu \mathrm{M} \mathrm{U}(\mathrm{VI})$. We can also hypothesize that the toxicity of $U$ led to the impairment of cellular function, which was consequently overwhelmed by this massive entrance of $U$.

\subsection{U adsorption, accumulation and release mechanisms}

In this study, we evidenced two different mechanisms involved in the removal of $\mathrm{U}(\mathrm{VI})$ by the Microbacterium sp. A9 strain. A first mechanism occurred within $30 \mathrm{~min}$ at both temperatures, and was considered to be metabolism-independent. Such a mechanism has already been reported for a large number of bacterial strains. It has been interpreted as adsorption of $\mathrm{U}(\mathrm{VI})$ to the bacterial surface due to electrostatic interactions between uranyl and high affinity sites of the cell envelope $[8,35]$. This type of interaction is in line with the FTIR results for the Microbacterium sp. A9 strain, which show that after $30 \mathrm{~min}$, $\mathrm{U}$ was coordinated mainly to the carboxyl and phosphoryl groups at both temperatures. In addition to this adsorption at the cell surface, a rapid metabolism-independent accumulation of $U$ inside the cells [5] resulting from membrane permeability [7] cannot be excluded, although we could not detect $U$ in the cells by TEM at early exposure time.

At $25^{\circ} \mathrm{C}$, immediately after $\mathrm{U}$ adsorption, the cells exposed to $10 \mu \mathrm{M} \mathrm{U}(\mathrm{VI})$ released a fraction of the metal, possibly as a protective mechanism. Since this release was observed only at $25^{\circ} \mathrm{C}$, we propose that it involves an active mechanism, such as an export system. Metal export systems are widespread and allow bacteria to survive in metal-contaminated environments [36]. The involvement of an efflux system in the detoxification of uranium has not yet been described, although an up-regulation of genes encoding metal efflux pumps has already been reported for Desulfotomaculum reducens exposed to $\mathrm{U}(\mathrm{VI})$ in anaerobic conditions [37]. In our study, $U$ release into the medium was only observable at the lowest exposure concentration. This suggests that exposure to higher $\mathrm{U}(\mathrm{VI})$ concentrations could either inhibit this mechanism or that massive entrance of $U$ in the cell masks this efflux.

Finally, a temperature-dependent removal of $\mathrm{U}(\mathrm{VI})$ was observed at longer timescales for the two U(VI) exposure concentrations, with a higher removal efficiency observed at $25^{\circ} \mathrm{C} v s .4^{\circ} \mathrm{C}$. Furthermore, the FTIR analysis showed a clear distinction in $\mathrm{U}(\mathrm{VI})$ coordination between the two temperatures: at $25^{\circ} \mathrm{C}$ phosphate groups are more and more involved as exposure time increased while at $4{ }^{\circ} \mathrm{C}$ the system remained stable. During this step of $\mathrm{U}(\mathrm{VI})$ removal, the formation of intracellular needle-like structures was observable by TEM. These structures were identified as autunite by the TRLFS analysis, which was coherent with the EDX analysis showing that $U$ was co-localised with P and Ca. The TRLFS data demonstrated also the presence of a second U-specie identified as $\mathrm{U}(\mathrm{VI})-\mathrm{Pi}$ complex. We cannot exclude that this species corresponds to U(VI)-ATP since they both exhibit a similar spectrum $[38,39]$. Taken together, these results suggest the involvement of a metabolism-dependent mechanism in the slow removal of $\mathrm{U}(\mathrm{VI})$, leading to the intracellular accumulation of $\mathrm{U}(\mathrm{VI})-\mathrm{Pi}$ and autunite.

Formation of autunite as a mechanism of $U(V I)$ sequestration has been reported in bacteria isolated from diverse areas including uranium-contaminated environments, [9,12,40,41]. Precipitation of autunite makes $U$ less available for complexation with proteins [23] or biomolecules [42], and therefore decreases its toxicity. Nedelkova et al. [12] clearly demonstrated the potential of three Microbacterium strains to immobilize a high quantity of $\mathrm{U}(\mathrm{VI})$ under aerobic conditions. These strains were able to precipitate $U$ in the bulk phase as well as on the cell surface at $\mathrm{pH} 4.5$ via the formation of a meta-autunite-like phase when exposed to $500 \mu \mathrm{M} \mathrm{U}(\mathrm{VI})$. We obtained comparable results with the Microbacterium sp. A9 strain, which also demonstrated a high potential for $U(V I)$ removal. One striking difference with our study, however, was the localisation of $\mathrm{U}(\mathrm{VI})$ inside the cell. It is possible that this resulted from the difference in $\mathrm{U}$ concentration and speciation, since in our study $\mathrm{U}(\mathrm{VI})$ was under its most bioavailable form. The ability of Microbacterium species to simultaneously tolerate high $\mathrm{U}(\mathrm{VI})$ exposure and accumulate it as autunite is remarkable. Indeed, our results imply that members of this genus could participate in the efficient immobilization and extraction of this heavy metal from soils. Since autunite is identified in contaminated sediments as the mineral phase controlling the long-term behavior of $U$ due to its stability over time [43], intracellular accumulation of $U$ as autunite mineral could thus be $a$ 
promising strategy for treatment and clean-up of U-contaminated sub-surfaces.

\section{Conclusions and perspectives}

Our data reveal that the Microbacterium sp. A9 strain, isolated from trench T22 at the Chernobyl waste repository, exhibits a high capacity of survival and resistance to $\mathrm{U}(\mathrm{VI})$ based on various detoxification mechanisms. Comparing data obtained at two temperatures and using experimental conditions where up to $100 \%$ cell viability was maintained have enabled the first-ever discrimination between active and passive mechanisms of $\mathrm{U}(\mathrm{VI})$ removal and the identification of an active release process. Three such mechanisms have been identified, all of which involve phosphate. The first one mediates phosphate release in the exposure media, which may complex with uranium to prevent its further entrance into the cells. The second one mediates the efflux of $U$ from the bacteria and is only visible when bacteria are exposed to low U concentration. The efflux of $U$ accompanies the release of phosphate, which may suggest that these mechanisms are linked together. The third detoxification mechanism is involved in precipitating accumulated uranium intracellularly as autunite. Based on these results, we propose a model of U-bacteria interactions (Fig. 7).

This study highlights the potential use of the Microbacterium genus for bioremediation. To validate the use of these bacteria in the clean-up of U-contaminated sub-surfaces, future research should be directed at investigating the behavior of these bacteria in situ, and determining the immobilization capacity of U in soils. Although we have proposed an interaction mechanism between $U$ and bacteria that incorporates our combined results, these mechanisms are far from being completely understood. Therefore, elucidating these efflux and detoxification mechanisms should be made a research priority in this field.

\section{Acknowledgements}

This work is financially supported by the CNRS and IRSN through the GNR TRASSE. We thank Sacha Pasquier for his technical assistance during TRLFS analysis. Nicolas Theodorakopoulos is the recipient of a PhD Grant co-funded by the IRSN and the PACA regional council. We thank Brandon Loveall of Improvence for English proofreading of the manuscript.

\section{References}

[1] W. De Vos, T. Tarvainen, Geochemical Atlas of Europe. Part 2-Interpretation of Geochemical Maps, Additional tables, Figures Maps and Related Publications (php) (2006) http://www.gsf.fi/publ/foregsatlas/part2

[2] V.A. Kashparov, N. Ahamdach, S.I. Zvarich, V.I. Yoschenko, I.M. Maloshtan, L. Dewiere, Kinetics of dissolution of Chernobyl fuel particles in soil in natural conditions, J. Environ. Radioact. 72 (2004) 335-353.

[3] V. Chapon, L. Piette, M.-H. Vesvres, F. Coppin, C. Le Marrec, R. Christen, N. Theodorakopoulos, L. Février, S. Levchuk, A. Martin-Garin, C. Berthomieu, C. Sergeant, Microbial diversity in contaminated soils along the T22 trench of the Chernobyl experimental platform, Appl. Geochem. 27 (2012) 1375-1383.

[4] M. Gavrilescu, L.V. Pavel, I. Cretescu, Characterization and remediation of soils contaminated with uranium, J. Hazard. Mater. 163 (2009) 475-510.

[5] M.L. Merroun, S. Selenska-Pobell, Bacterial interactions with uranium: an environmental perspective, J. Contam. Hydrol. 102 (2008) 285-295.

[6] L. Newsome, K. Morris, J.R. Lloyd, The biogeochemistry and bioremediation of uranium and other priority radionuclides, Chem. Geol. 363 (2014) 164-184.

[7] Y. Suzuki, J.F. Banfield, Resistance to and accumulation of uranium by bacteria from a uranium-contaminated site, Geomicrobiol. J. 21 (2004) 113-121.

[8] S. Choudhary, P. Sar, Uranium biomineralization by a metal resistant Pseudomonas aeruginosa strain isolated from contaminated mine waste, J. Hazard. Mater. 186 (2011) 336-343.

[9] M. Merroun, M. Nedelkova, A. Rossberg, C. Hennig, S. Selenska-Pobell, Interaction mechanisms of bacterial strains isolated from extreme habitats with uranium, Radiochim. Acta 94 (2006) 723-729.

[10] R. Kumar, M. Nongkhlaw, C. Acharya, S.R. Joshi, Uranium (U)-tolerant bacterial diversity from $\mathrm{U}$ ore deposit of domiasiat in north-east india and its prospective utilisation in bioremediation, Microbes Environ. 28 (2013) 33-41.
[11] L. Mondani, K. Benzerara, M. Carrière, R. Christen, Y. Mamindy-Pajany, L. Février, N. Marmier, W. Achouak, P. Nardoux, C. Berthomieu, V. Chapon, Influence of uranium on bacterial communities: a comparison of natural uranium-rich soils with controls, PLoS ONE 6 (2011) e25771.

[12] M. Nedelkova, M.L. Merroun, A. Rossberg, C. Hennig, S. Selenska-Pobell, Microbacterium isolates from the vicinity of a radioactive waste depository and their interactions with uranium, FEMS Microbiol. Ecol. 59 (2007) 694-705.

[13] T.N. Nazina, E.A. Luk'yanova, E.V. Zakharova, L.I. Konstantinova, S.N. Kalmykov, A.B. Poltaraus, A.A. Zubkove, Microorganisms in a disposal site for liquid radioactive wastes and their influence on radionuclides, Geomicrobiol. J. 27 (2010) 473-486.

[14] P. Kaushik, N. Rawat, M. Mathur, P. Raghuvanshi, P. Bhatnagar, H. Swarnkar, S. Flora, Arsenic hyper-tolerance in four Microbacterium species isolated from soil contaminated with textile effluent, Toxicol. Int. 19 (2012) 188-194.

[15] D. Bugai, V. Kashparov, L. Dewiére, Y. Khomutinin, S. Levchuk, V. Yoschenko, Characterization of subsurface geometry and radioactivity distribution in the trench containing Chernobyl clean-up wastes, Environ. Geol. 47 (2005) 869-881.

[16] F. Osmond, Dosage colorimétrique du phosphore, Bull. Soc. chim. (Paris) 47 (1887) 745-748

[17] T. Vercouter, P. Vitorge, B. Amekraz, C. Moulin, Stoichiometries and thermodynamic stabilities for aqueous sulfate complexes of $\mathrm{U}(\mathrm{VI})$, Inorg. Chem. 47 (2008) 2180-2189.

[18] R Core Team, R: A Language and Environment for Statistical Computing, R Foundation for Statistical Computing, Vienna, Austria, 2013 http://www.R-project.org

[19] S.J. Markich, Uranium speciation and bioavailability in aquatic systems: an overview, Sci. World J. 2 (2002) 707-729.

[20] T. Reitz, M.L. Merroun, A. Rossberg, R. Steudtner, S. Selenska-Pobell, Bioaccumulation of U(VI) by Sulfolobus acidocaldarius under moderate acidic conditions, Radiochim. Acta 99 (2011) 543-553.

[21] K. Popa, A. Cecal, G. Drochioiu, A. Pui, D. Humelnicu, Saccharomyces cerevisiae as uranium bioaccumulating material: the influence of contact time, $\mathrm{pH}$ and anion nature, Nukleonika 48 (2003) 121-125

[22] A. Barkleit, H. Foerstendorf, B. Li, A. Rossberg, H. Moll, G. Bernhard, Coordination of uranium(VI) with functional groups of bacterial lipopolysaccharide studied by EXAFS and FT-IR spectroscopy, Dalton Trans. 40 (2011) 9868-9876

[23] R. Pardoux, S. Sauge-Merle, D. Lemaire, P. Delangle, L. Guilloreau, J.-M. Adriano, C. Berthomieu, Modulating uranium binding affinity in engineered calmodulin EF-hand peptides: effect of phosphorylation, PLoS ONE 7 (2012) e41922.

[24] A.C. Humphries, K.P. Nott, L.D. Hall, L.E. Macaskie, Reduction of $\mathrm{Cr}(\mathrm{VI})$ by immobilized cells of Desulfovibrio vulgaris NCIMB 8303 and Microbacterium sp. NCIMB 13,776, Biotechnol. Bioeng. 90 (2005) 589-596.

[25] A. Achour-Rokbani, A. Cordi, P. Poupin, P. Bauda, P. Billard, Characterization of the ars gene cluster from extremely arsenic-resistant Microbacterium sp. strain A33, Appl. Environ. Microbiol. 76 (2010) 948-955.

[26] L. Achbergerová, J. Nahálka, Polyphosphate - an ancient energy source and active metabolic regulator, Microb. Cell Fact. 4 (2011) 10-63.

[27] V. Sivaswamy, M.I. Boyanov, B.M. Peyton, S. Viamajala, R. Gerlach, W.A. Apel, R.K. Sani, A. Dohnalkova, K.M. Kemner, T. Borch, Multiple mechanisms of uranium immobilization by Cellulomonas sp. strain ES6, Biotechnol. Bioeng. 108 (2011) 264-276.

[28] M.J. Beazley, R.J. Martinez, P.A. Sobecky, S.M. Webb, M. Taillefert, Uranium biomineralization as a result of bacterial phosphatase activity: insights from bacterial isolates from a contaminated subsurface, Environ. Sci. Technol. 41 (2007) 5701-5707.

[29] R.J. Martinez, M.J. Beazley, M. Taillefert, A.K. Arakaki, J. Skolnick, P.A. Sobecky, Aerobic uranium (VI) bioprecipitation by metal-resistant bacteria isolated from radionuclide- and metal-contaminated subsurface soils, Environ. Microbiol. 9 (2007) 3122-3133.

[30] M.L. Merroun, M. Nedelkova, J.J. Ojeda, T. Reitz, M.L. Fernández, J.M. Arias, M. Romero-González, S. Selenska-Pobell, Bio-precipitation of uranium by two bacterial isolates recovered from extreme environments as estimated by potentiometric titration, TEM and X-ray absorption spectroscopic analyses, J. Hazard. Mater. 197 (2011) 1-10.

[31] J.A. Finlay, V.J. Allan, A. Conner, M.E. Callow, G. Basnakova, L.E. Macaskie, Phosphate release and heavy metal accumulation by biofilm-immobilized and chemically-coupled cells of a Citrobacter sp. pre-grown in continuous culture, Biotechnol. Bioeng. 63 (1999) 87-97.

[32] L. Lütke, H. Moll, G. Bernhard, Insights into the uranium (VI) speciation with Pseudomonas fluorescens on a molecular level, Dalton Trans. 41 (2012) 13370-13378.

[33] J. Misson, P. Henner, M. Morello, M. Floriani, T.D. Wu, J.-L. Guerquin-Kern, L. Février, Use of phosphate to avoid uranium toxicity in Arabidopsis thaliana leads to alterations of morphological and physiological responses regulated by phosphate availability, Environ. Exp. Bot. 67 (2009) 353-362.

[34] A.E. Ray, J.R. Bargar, V. Sivaswamy, A.C. Dohnalkova, Y. Fujita, B.M. Peytond, T.S. Magnusona, Evidence for multiple modes of uranium immobilization by an anaerobic bacterium, Geochim. Cosmochim. Acta 75 (2011) 2684-2695.

[35] D. Gorman-Lewis, P.E. Elias, J.B. Fein, Adsorption of aqueous uranyl complexes onto Bacillus subtilis cells, Environ. Sci. Technol. 39 (2005) 4906-4912. 
[36] D.H. Nies, Efflux-mediated heavy metal resistance in prokaryotes, FEMS Microbiol. Rev. 27 (2003) 313-339.

[37] P. Junier, E.D. Vecchia, R. Bernier-Latmani, The response of Desulfotomaculum reducens $\mathrm{MI}-1$ to $\mathrm{U}(\mathrm{VI})$ exposure: a transcriptomic study, Geomicrobiol. J. 28 (2011) 483-496.

[38] M.L. Merroun, G. Geipel, R. Nicolai, K.H. Heise, S. Selenska-Pobell, Complexation of uranium (VI) by three eco-types of Acidithiobacillus ferrooxidans studied using time-resolved laser-induced fluorescence spectroscopy and infrared spectroscopy, BioMetals 16 (2003) 331-339.

[39] N. Renninger, R. Knopp, H. Nitsche, D.S. Clark, J.D. Keasling, Uranyl precipitation by Pseudomonas aeruginosa via controlled polyphosphate metabolism, Appl. Environ. Microbiol. 70 (2004) 7404-7412.

[40] F. Jroundi, M.L. Merroun, J.M. Arias, A. Rossberg, S. Selenska-Pobell, M.T. González-Muñoza, Spectroscopic and microscopic characterization of uranium biomineralization in Myxococcus xanthus, Geomicrobiol. J. 24 (2007) 441-449

[41] E. Krawczyk-Bärsch, H. Lünsdorf, K. Pedersen, T. Arnold, F. Bok, R. Steudtner, A. Lehtinen, V. Brendler, Immobilization of uranium in biofilm microorganisms exposed to groundwater seeps over granitic rock tunne walls in Olkiluoto, Finland, Geochim. Cosmochim. Acta 96 (2012) 94-104.

[42] S. Frelon, S. Mounicou, R. Lobinski, R. Gilbin, O. Simon, Subcellular fractionation and chemical speciation of uranium to elucidate its fate in gills and hepatopancreas of crayfish Procambarus clarkia, Chemosphere 91 (2013) 481-490.

[43] D.M. Wellman, J.P. Icenhower, A.P. Gamerdinger, S.W. Forrester, Effects of pH, temperature, and aqueous organic material on the dissolution kinetics of meta-autunite minerals, $(\mathrm{Na}, \mathrm{Ca})_{2-1}\left[\left(\mathrm{UO}_{2}\right)\left(\mathrm{PO}_{4}\right)\right]_{2} \cdot 3 \mathrm{H}_{2} \mathrm{O}$, Am. Mineral. 91 (2006) 143-158. 